\title{
Functional Mechanotransduction Is Required for Cisplatin- Induced Hair Cell Death in the Zebrafish Lateral Line
}

\author{
Andrew J. Thomas, ${ }^{1,2}$ Dale W. Hailey, ${ }^{1,3}$ Tamara M. Stawicki, ${ }^{1,3}$ Patricia Wu, ${ }^{1,2}$ Allison B. Coffin, ${ }^{1,2}$ Edwin W Rubel, ${ }^{1,2}$ \\ David W. Raible, ${ }^{1,3}$ Julian A. Simon, ${ }^{4}$ and Henry C. $\mathbf{O} \mathbf{u}^{1,2,5}$ \\ ${ }^{1}$ Virginia Merrill Bloedel Hearing Research Center, ${ }^{2}$ Department of Otolaryngology-Head and Neck Surgery, and ${ }^{3}$ Department of Biological Structure, \\ University of Washington, Seattle, Washington 98195, ${ }^{4}$ Fred Hutchinson Cancer Research Center, Seattle, Washington 98109, and ${ }^{5}$ Seattle Children's \\ Hospital, Seattle, Washington 98105
}

Cisplatin, one of the most commonly used anticancer drugs, is known to cause inner ear hair cell damage and hearing loss. Despite much investigation into mechanisms of cisplatin-induced hair cell death, little is known about the mechanism whereby cisplatin is selectively toxic to hair cells. Using hair cells of the zebrafish lateral line, we found that chemical inhibition of mechanotransduction with quinine and EGTA protected against cisplatin-induced hair cell death. Furthermore, we found that the zebrafish mutants mariner (myo7aa) and sputnik (cad23) that lack functional mechanotransduction were resistant to cisplatin-induced hair cell death. Using a fluorescent analog of cisplatin, we found that chemical or genetic inhibition of mechanotransduction prevented its uptake. These findings demonstrate that cisplatin-induced hair cell death is dependent on functional mechanotransduction in the zebrafish lateral line.

\section{Introduction}

Cisplatin is a widely used and highly effective anticancer drug. In developed countries, it is also the most commonly used ototoxin, a heterogeneous class of compounds that cause inner ear damage. Hearing loss from cisplatin has been largely underestimated, and is now believed to occur in up to $80 \%$ of patients treated with cisplatin (Rybak, 1981; Skinner et al., 1990; Knight et al., 2005, 2007). There is currently no U.S. Food and Drug Administrationapproved drug or treatment known to prevent cisplatin-induced hearing loss. Most cancer patients have no alternative and must accept that hearing loss, often debilitating, is a likely consequence of their treatment. While a number of different mechanisms have been proposed for how cisplatin damages hair cells after entering the cell, the mechanism of uptake into hair cells is not well understood. Cisplatin uptake has been hypothesized to be similar to that seen in cancer cells, in which the copper transporter Ctr 1 and the organic cation transporter Oct2 have been demonstrated to play important roles (Ishida et al., 2002; Stewart, 2007; Filipski et al., 2008).

The uptake of cisplatin has been studied in vitro in hair cell lines (More et al., 2010) as well as in neonatal rat organ of Corti

Received Aug. 14, 2012; revised Dec. 26, 2012; accepted Jan. 25, 2013.

Author contributions: A.J.T., D.W.H., A.B.C., E.W.R., D.W.R., J.A.S., and H.C.O. designed research; A.J.T., D.W.H., T.M.S., and P.W. performed research; A.J.T., D.W.H., T.M.S., P.W., E.W.R., D.W.R., J.A.S., and H.C.O. analyzed data; A.J.T. and H.C.O. wrote the paper.

This work was supported by NIH-NIDCD Grants K08DC009631, P30-DC004661, T32DC000018, R01-DC009807, and R01-DC005987-05 and a grant from the Capita Foundation.

The authors declare no competing financial interests.

Correspondence should be addressed to Henry C. Ou, University of Washington, Virginia Merrill Bloedel Hearing Research Center, Box 357923, Seattle, WA 98195-7293. E-mail: henryou@u.washington.edu.

A. B. Coffin's present address: Neuroscience Program, Washington State University Vancouver, Vancouver, WA 98686.

DOI:10.1523/JNEUROSCI.3940-12.2013

Copyright $\odot 2013$ the authors $\quad 0270-6474 / 13 / 334405-10 \$ 15.00 / 0$ explants (Ding et al., 2011). Within the inner ear, Ctr 1 expression has been found in inner and outer hair cells, stria vascularis, and spiral ganglia (More et al., 2010). Inhibition of Ctr1 using lowconcentration copper sulfate reduces cisplatin-induced hair cell death (More et al., 2010; Ding et al., 2011). Similarly, Oct2 has also been proposed to mediate cisplatin-induced ototoxicity, with inhibition of Oct 2 by cimetidine leading to protection against cisplatin-induced hearing loss in mice (Ciarimboli et al., 2010).

The zebrafish lateral line is a well-established model for studying hair cell biology. Lateral line hair cells share mechanisms of mechanotransduction (MET) with hair cells of the inner ear. Multiple studies have demonstrated that like mammalian hair cells, zebrafish lateral line hair cells die in response to ototoxins such as aminoglycosides and cisplatin (Williams and Holder, 2000; Harris et al., 2003; Ton and Parng, 2005; Ou et al., 2007; Chiu et al., 2008).

We performed chemical and genetic manipulations to examine mechanisms of cisplatin uptake into zebrafish lateral line hair cells and found that functional mechanotransduction was required for cisplatin-dependent hair cell death. Chemical inhibition of Oct 2 and Ctr1 did not significantly affect cisplatininduced hair cell death. We then characterized a commercially available rhodamine-conjugated platinum reagent ( $\mathrm{Rho}-\mathrm{Pt})$ as a tool for studying cisplatin uptake. We compared hair cell death caused by Rho-Pt to that of unconjugated cisplatin and characterized the kinetics of uptake of Rho-Pt into hair cells of the zebrafish lateral line. Interventions that reduced cisplatininduced hair cell death also reduced uptake of Rho-Pt, suggesting that Rho-Pt can be effectively used to study cisplatin uptake.

\section{Materials and Methods}

Animals. Zebrafish (Danio rerio) embryos of either sex were produced by paired matings of adult fish maintained at the University of Washington 
zebrafish facility by standard methods (Westerfield, 2000). We used AB wild-type, as well as mariner $^{\text {ty220, }}$ sputnik ${ }^{\text {tj264a, and }} \operatorname{Tg}$ (pou4f3: gap43-GFP) $)^{5356 t}$ zebrafish strains. Mariner and sputnik are circler mutants originally discovered in a large-scale zebrafish genetic screen (Granato et al., 1996) and identified to have mutations in myosin VIIAa (Ernest et al., 2000) and cadherin 23 (Söllner et al., 2004), respectively. The $\mathrm{Tg}$ (pou4f3:gap43-GFP) transgenic zebrafish express green fluorescent protein (GFP) in hair cells of the lateral line and inner ear under control of the pou $f 33$ (brn3c) promoter and are targeted to the plasma membrane with a GAP-43 membrane targeting sequence (Xiao et al., 2005); hereafter, we designate this transgenic line brn3c:mGFP.

Embryos were maintained in fish embryo media (EM; $1 \mathrm{~mm} \mathrm{MgSO}_{4}, 120 \mu \mathrm{M} \mathrm{K}_{2} \mathrm{PO}_{4}, 74$ $\mu \mathrm{M} \mathrm{Na}{ }_{2} \mathrm{HPO}_{4}, 1 \mathrm{mM} \mathrm{CaCl}_{2}, 500 \mu \mathrm{M} \mathrm{KCl}, 15 \mu \mathrm{M}$ $\mathrm{NaCl}$, and $500 \mu \mathrm{M} \mathrm{NaHCO}{ }_{3}$ in $\mathrm{dH}_{2} \mathrm{O}$ ) at a density of 50 animals per $100 \mathrm{~mm}^{2}$ Petri dish and kept in an incubator at $28.5^{\circ} \mathrm{C}$. At $4 \mathrm{~d}$ postfertilization (dpf), larvae were fed live paramecia. All zebrafish procedures described were approved by the University of Washington Animal Care and Use Committee.

Materials. Cisplatin solution ( $1 \mathrm{mg} / \mathrm{ml}$ in sodium chloride) was obtained from the University of Washington Pharmacy (Seattle, WA) and the $\mathrm{pH}$ adjusted to equal that of EM. Rhodamine-Universal Labeling System (RHOULS; referred to here as Rho-Pt) was obtained from Kreatech Diagnostics. Rho-Pt consists of 6-carboxytetramethylrhodamine (6-TAMRA) coupled to the Universal Linkage System (ULS) molecule. Identity and purity of the compound were confirmed by mass spectroscopy and HPLC using an Agilent 6130 Quadrupole LC/MS system with Agilent 1260 Infinity HPLC and an Agilent Poroshell 120 SB-C18 $2.7 \mu \mathrm{m}$ column (Agilent Technologies). The small amount of impurities $(<20 \%)$ in the Rho-Pt solution include the hydrolyzed form of ULS, which has a hydroxyl leaving group instead of chlorine, as well as some unconjugated hydrolyzed 6-TAMRA. Purified 6-TAMRA, the single isomer of 5(6)-TAMRA, was obtained from Anaspec and used to assess uptake and toxicity of unconjugated 6-TAMRA. Quinine (catalog \#22620), cimetidine (catalog \#C4522), and neomycin sulfate $10 \mathrm{mg} / \mathrm{ml} \mathrm{so-}$ lution (catalog \#N1142) were obtained from Sigma. Copper solutions were prepared by dissolving copper(II) sulfate pentahydrate (Fluka) in EM. All solutions were diluted in EM.

Application of potential cisplatin uptake modulators. Free-swimming 5 dpf zebrafish larvae were transferred into a 48 well plate at a density of $10-12$ fish per well using a wide-bore glass pipette. Potential protectants to be evaluated against a hair cell toxicant (cisplatin, Rho-Pt, or neomycin) were aliquoted into their appropriate well, and larvae were incubated at $28.5^{\circ} \mathrm{C}$ for $1 \mathrm{~h}$ pretreatment, with the exception of copper pretreatment for $20 \mathrm{~min}$. A hair cell toxicant was then added, and the larvae were cotreated with the toxicant and potential protectant present at $28.5^{\circ} \mathrm{C}$. All modulating compounds were also assessed individually to determine whether they exhibited toxicity to lateral line hair cells. To thoroughly test protection against a range of concentrations and durations, we tested modulating compounds against both short- $(6 \mathrm{~h})$ and long-duration (24 h) cisplatin protocols. Low concentrations $(50-100 \mu \mathrm{M})$ of cisplatin cause lateral line hair cell death after $24 \mathrm{~h}$, while higher concentrations $(250-500 \mu \mathrm{M})$ are toxic after $6 \mathrm{~h}$ (Ou et al., 2007; Vlasits et al., 2012). While we have not seen evidence that these short- and long-duration protocols cause damage through different pathways, we have observed this phenomenon with aminoglycosides in the zebrafish lateral line (Owens et al., 2009). As a result, we evaluated protection against both shortand longer-duration protocols in the event that there were different b

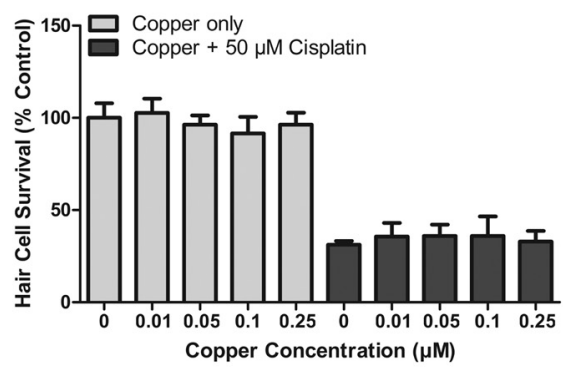

d

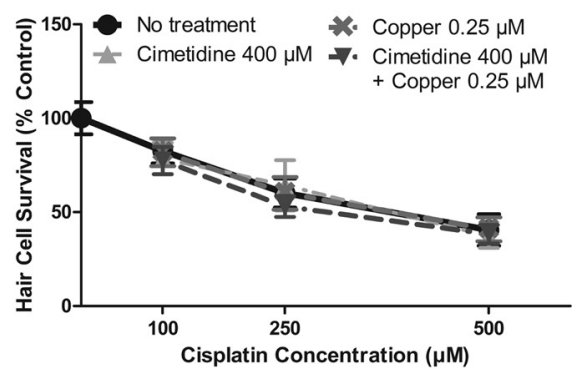

Figure 1. Low-concentration copper and/or cimetidine treatment does not prevent cisplatin-induced hair cell death. $\boldsymbol{a}$, Doseresponse functions for treatment with cimetidine before $50 \mu \mathrm{m}$ cisplatin for $24 \mathrm{~h}$. Increasing concentrations of cimetidine did not one or low-concentration copper before $50 \mu \mathrm{m}$ cisplatin for $24 \mathrm{~h}$. Copper concentrations of $0.01-0.25 \mu \mathrm{m}$ alone did not cause sicicant hair cell toxicity. When used before and during cisplatin treatment, there was no significant protection against cisplatin-

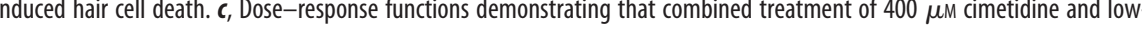
copper and $400 \mu \mathrm{m}$ cimetidine did not significantly protect against cisplatin treatment of 100, 250, or $500 \mu \mathrm{m}$ for $6 \mathrm{~h}$. For all treatment groups $(\boldsymbol{a}-\boldsymbol{d}), n=9-12$ fish. Error bars indicate SD. ${ }^{* * *} p<0.001$ by one-way ANOVA and Tukey-Kramer post-test.

mechanisms of damage. After toxicant exposure, larvae were anesthetized with MS-222 (3-aminobenzoic acid ethyl ester, methanesulfonate salt; Sigma-Aldrich) and then fixed overnight in $4 \%$ paraformaldehyde (PFA) at $4^{\circ} \mathrm{C}$.

Immunocytochemistry and hair cell counts. After fixation in PFA, larvae were rinsed in PBS and then incubated in blocking solution [1\% Triton-X, 5\% normal goat serum (NGS) in PBS] for 1-2 h at room temperature. Larvae were then incubated overnight at $4^{\circ} \mathrm{C}$ in antiparvalbumin primary antibody (monoclonal, 1:400 in 1\% Triton-X, 1\% NGS in PBS; Millipore) to label hair cells. After primary antibody labeling, larvae were rinsed in 1\% Triton-X in PBS and then incubated for 2-4 $\mathrm{h}$ at room temperature in Alexa 488 goat anti-mouse fluorescent antibody solution (1:500 in 1\% Triton-X, 1\% NGS in PBS; Invitrogen) secondary antibody. The larvae were then rinsed and mounted between two coverslips in Fluoromount-G (Southern Biotech) for imaging. A Zeiss Axioplan II microscope using a FITC filter set at a final magnification of $200 \times$ was used to count hair cells from the SO1, SO2, O1, and OC1 neuromasts (Raible and Kruse, 2000). Approximately 10 fish were studied per treatment group. Results are presented as the mean hair cell survival as a percentage of the control group treated only in EM. Error bars in figures indicate $\pm 1 \mathrm{SD}$.

Rho-Pt dose-response. To assess toxicity of Rho-Pt, $5 \mathrm{dpf}$ zebrafish larvae were incubated in 0 to $200 \mu \mathrm{M}$ cisplatin and/or Rho-Pt solution for $24 \mathrm{~h}$ at $28.5^{\circ} \mathrm{C}$. The fish were then anesthetized with MS-222 and fixed with $4 \%$ PFA overnight at $4^{\circ} \mathrm{C}$.

Tip link-breaking experiments. Zebrafish larvae were exposed to regular EM (controls) or EM with no calcium and $5 \mathrm{~mm}$ EGTA for $20 \mathrm{~min}$. The fish were then rinsed three times for $1 \mathrm{~min}$ each in fresh EM (normal EM, $1 \mathrm{~mm}$ calcium) to avoid confounding effects of depleted calcium levels on hair cell survival. Each basket was then transferred to a well containing either EM alone, $500 \mu \mathrm{M}$ cisplatin, $100 \mu \mathrm{M}$ neomycin, or $50 \mu \mathrm{M}$ Rho-Pt for $1 \mathrm{~h}$ at $28.5^{\circ} \mathrm{C}$. A single $1 \mathrm{~h}$ treatment was used for $100 \mu \mathrm{M}$ neomycin and $50 \mu \mathrm{M}$ Rho-Pt. Previous studies in zebrafish demonstrated some 

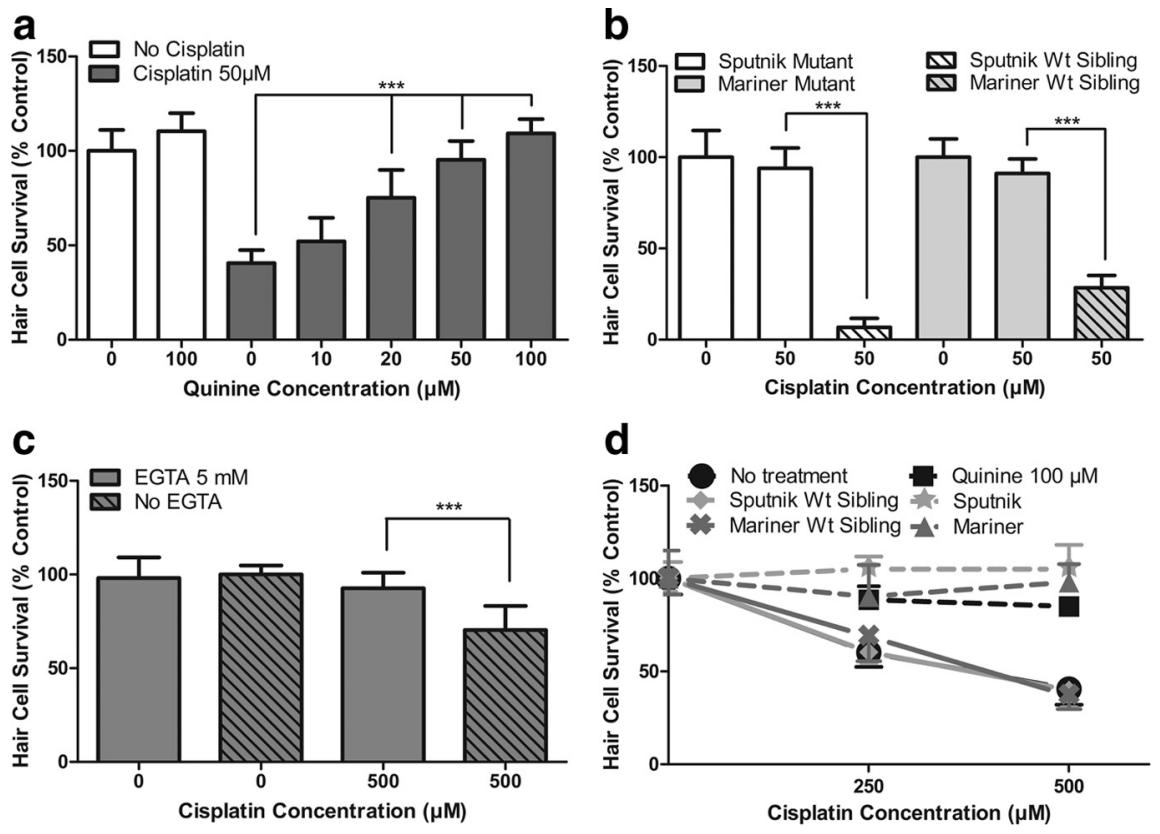

Figure 2. Functional mechanotransduction is required for cisplatin-induced hair cell death in the zebrafish lateral line. $\boldsymbol{a}$ Inhibition of mechanotransduction with quinine pretreatment led to significant dose-dependent protection against cisplatininduced hair cell death ( $p<0.001$, one-way ANOVA). $\boldsymbol{b}$, Transgenic mutants lacking functional mechanotransduction are protected against cisplatin-induced hair cell death. sputnik and mariner mutants demonstrate significant protection against $50 \mu \mathrm{M}$ cisplatin for $24 \mathrm{~h}$ compared to wild-type (Wt) siblings ( $p<0.001$, Tukey-Kramer post-test). c, Tip link breakage using $5 \mathrm{~mm} \mathrm{EGTA}$ chelation resulted in significant protection against $4 \mathrm{~h}$ exposure to $500 \mu \mathrm{m}$ cisplatin ( $p<0.001$, Tukey-Kramer post-test). $\boldsymbol{d}$, Protection afforded by quinine, sputnik, and mariner is maintained with higher-concentration, shorter-duration cisplatin damage protocols. Pretreatment with $100 \mu \mathrm{m}$ quinine results in significant protection against 250 and $500 \mu \mathrm{m}$ cisplatin for $6 \mathrm{~h}(p<0.001$, Tukey-Kramer post-test). Similarly, sputnik and mariner mutants exhibit significant protection against $250 \mu \mathrm{m}$ cisplatin $(6 \mathrm{~h}$ treatment; $p<0.001$ sputnik and $p<0.01$ mariner, Tukey-Kramer post-test) or $500 \mu \mathrm{m}$ cisplatin ( $6 \mathrm{~h}$ treatment; $p<0.001$, Tukey-Kramer post-test) compared to Wt siblings. For all treatment groups, $n=9-13$ fish. Error bars indicate SD. ${ }^{* * *} p<0.001$ by one-way ANOVA and Tukey-Kramer post-test.

recovery of tip links by $4 \mathrm{~h}$ after treatment (Suli et al., 2012). To prevent any tip link recovery during the experiment, the $4 \mathrm{~h}$ cisplatin treatment was subdivided into four $1 \mathrm{~h}$ cisplatin treatments, each proceeded by an additional 20 min chelation step to break any reformed tip links.

Rho-Pt uptake. To assess uptake of Rho-Pt, $5 \mathrm{dpf}$ zebrafish larvae were pretreated with either EM only (control), a modulator of copper transport (cimetidine or copper sulfate), or a mechanotransduction inhibitor (quinine or EGTA). Larvae were then incubated in $50 \mu \mathrm{M}$ Rho-Pt for 15, 60 , or $240 \mathrm{~min}$ and then rinsed twice in EM. For experiments requiring nuclear labeling, larvae were then treated with SYTOX Green ( $5 \mu \mathrm{M}$ for 1 min; Invitrogen) to label neuromast hair cell nuclei. Larvae were then rinsed twice in EM and anesthetized in $0.001 \%$ MS-222 in EM before imaging.

FM1-43 uptake. To assess the efficacy of mechanotransduction blockade, FM1-43 (Invitrogen) uptake into lateral line hair cells was examined. Zebrafish larvae ( $5 \mathrm{dpf}$ ) were pretreated with a mechanotransduction inhibitor (quinine or EGTA) followed by treatment with FM1-43 (3 $\mu \mathrm{M}$ for $30 \mathrm{~s}$ ). Larvae were then rinsed twice in EM and anesthetized before imaging.

Live imaging. Fish were anesthetized in MS-222 and then transferred to a Lab-Tek Chambered Coverglass slide (Nunc) containing $2 \mathrm{ml}$ of $0.001 \%$ MS-222 in EM. The larva was immobilized with 112 micron nylon mesh and two stainless-steel slice hold-downs (model SHD26GH/10; Warner Instruments). Approximately five neuromasts were imaged per larva and were selected from the SO3, O1, OC1, D1, MI2, MI1, O2, OP1, M2, or IO4 neuromasts (Raible and Kruse, 2000), depending on visibility and fish orientation. Image stacks were obtained using SlideBook 5.0 software (Intelligent Imaging Innovations) running a Marianas spinning disk confocal system (an Observer inverted microscope; Zeiss), Evolve $512 \times 512$ camera (Photometrics), and Piezo XYZ microscope stage (Applied Scientific Instrumentation). Consistent imaging parameters were used for all groups: a $488 \mathrm{~nm}$ laser exposure time of $4 \mathrm{~ms}$ and intensification of 450 were used for visualizing nuclear labeling with SYTOX Green, a 561 laser exposure time of $40 \mathrm{~ms}$ with intensification of 100 was used for visualization of Rho-Pt, and DIC images were obtained after fluorescent images as either a single midvolume plane or a complete $z$ stack. Flat-field correction was used for all images. Optical volumes collected with a Zeiss $63 \times / 1.2 \mathrm{~W}$ C-Apochromat waterimmersion objective (1.2 numerical aperture), at $0.2116 \mu \mathrm{m} /$ pixel and $0.5 \mu \mathrm{m} \mathrm{z}$ steps, were exported as 16 bit TIFF image stacks and analyzed using Fiji software (Schindelin et al., 2012).

Image analysis. Rho-Pt uptake in the entire neuromast was measured from a summed intensity projection of the neuromast following correction for specimen background intensities. Background fluorescence was measured in each image slice from a representative region of interest (ROI) defined adjacent to the neuromast. This mean ROI intensity was subtracted from its respective slice throughout the stack. An ROI was drawn around the neuromast boundary and applied to a summed intensity projection of the background corrected stack for measurement of raw integrated density. These results are reported as the mean and SD of the summed intensities for all neuromasts measured within the treatment group.

Fluorescence changes for hair cell nuclei within a neuromast were quantified using a nuclear mask generated using the signal of a SYTOX Green nucleic acid label. A summed intensity projection image of this was created and total Rho-Pt nuclear intensity measured as the summed intensities in the stack. Nuclear Rho-Pt fluorescence intensity is reported as the mean and SD for all neuromasts measured in the treatment group.

Whole-mount in situ hybridization. Zebrafish larvae ( $5 \mathrm{dpf}$ ) were used for in situ hybridization. Larvae were fixed in $4 \%$ paraformaldehyde for $2 \mathrm{~h}$ at room temperature and stored in $100 \%$ methanol at $-20^{\circ} \mathrm{C}$ before preceding with hybridization. Additionally, larvae were treated with 10 $\mu \mathrm{g} / \mathrm{ml}$ proteinase $\mathrm{K}$ for $30 \mathrm{~min}$. In situ hybridization was performed as described previously (Thisse and Thisse, 2008). The Ctr1 probe was generated from a template of the full-length coding cDNA of Ctr1 in the PCRII vector. The Oct2 in situ probe was generated using a full-length Oct 2 clone including some untranslated region (Open Biosystems; clone 6793882). Antisense probes for Oct 2 were created by linearizing the vector at both XhoI $(\sim 1.9 \mathrm{~kb})$ and BstxI $(\sim 800 \mathrm{bp})$ sites.

Statistics. To compare groups, Student's $t$ test as well as one-way and two-way ANOVA with Tukey's post hoc tests were used as appropriate. Statistical tests were performed using GraphPad Prism version 5.01 for Windows (GraphPad Software). Statistical significance was defined as $p<0.05$ for all comparisons.

\section{Results}

Inhibition of Oct 2 and Ctr1 does not affect cisplatin-induced hair cell death in zebrafish lateral line hair cells

Both Oct2 and Ctr1 have been proposed as key regulators of cisplatin uptake into hair cells. We evaluated the role of these two transporters in regulating cisplatin-induced toxicity in zebrafish lateral line hair cells using cimetidine as a competitive inhibitor of Oct2 and low-concentration copper as a competitive inhibitor of Ctr1. It is important to note that previous in situ hybridization studies for Oct2 did not demonstrate detectable expression in zebrafish hair cells (Thisse et al., 2004; McDermott et al., 2007). We performed in situ hybridization with an Oct2 probe and 
found no detectable expression in hair cells (data not shown). However, in light of the previous mammalian findings (Ciarimboli et al., 2010), and the possibility that low-level expression in hair cells might elude detection by in situ hybridization, we examined whether cimetidine would inhibit cisplatin-induced hair cell death in the zebrafish. A wide concentration range of cimetidine $(20-400 \mu \mathrm{M})$ was used to cover reported $\mathrm{IC}_{50}$ values for inhibition of Oct2 ranging from 110 to $373 \mu \mathrm{M}$ (Okuda et al., 1999; Minematsu et al., 2010). Zebrafish were pretreated with cimetidine for $1 \mathrm{~h}$, followed by cotreatment with $50 \mu \mathrm{M}$ cisplatin for an additional $24 \mathrm{~h}$. We found no significant protection against cisplatin-induced hair cell loss for all concentrations of cimetidine evaluated $(p>0.05$, one-way ANOVA; Fig. 1a).

To evaluate the role of the Ctr 1 copper transporter in cisplatin toxicity, we used a low concentration of copper sulfate that acts as a competitive inhibitor of Ctr1 (More et al., 2010; Ding et al., 2011). McDermott et al. (2007) previously examined Ctr 1 expression in the zebrafish and found expression in multiple tissues including hair cells. We performed in situ hybridization using a Ctr1 probe and found broad expression throughout the embryo (data not shown). Zebrafish larvae were pretreated for 20 min with copper concentrations ranging from 0.01 to $0.25 \mu \mathrm{M}$. These concentrations were chosen because they are below the level at which we and others have observed significant hair cell toxicity from copper in zebrafish (Hernández et al., 2006; Mackenzie and Raible, 2012). The zebrafish were then cotreated with copper and $50 \mu \mathrm{M}$ cisplatin for $24 \mathrm{~h}$. We found no significant protection against cisplatin-induced hair cell loss for all concentrations of copper evaluated $(p>0.05$, one-way ANOVA; Fig. 1b).

Although neither low-concentration copper nor cimetidine treatment independently provided significant protection against cisplatin-induced hair cell death, we explored the possibility that the two chemical inhibitors could have a significant effect when combined. In other systems, cimetidine provides additional reduction of cisplatin uptake and toxicity in Ctr1-downregulated cells (Pabla et al., 2009). We treated larvae with $400 \mu \mathrm{M}$ cimetidine and a concentration range of copper $(0.05$ to $0.5 \mu \mathrm{M})$, then added $50 \mu \mathrm{M}$ cisplatin and cotreated for $24 \mathrm{~h}$. As shown in Figure $1 c$, the combination of cimetidine and low dose copper did not provide significant protection against $24 \mathrm{~h}$ cisplatin damage $(p>$ 0.05, one-way ANOVA).

We then examined whether protection would be seen against a shorter-duration but higher-concentration cisplatin damage protocol. Blockers of Oct 2 and Ctr1 were tested against 100-500 $\mu \mathrm{M}$ cisplatin for $6 \mathrm{~h}$. We found no significant protection of cimetidine, copper, or a combination of both cimetidine and copper against any concentration of cisplatin using this higher concentration cisplatin damage protocol ( $p>0.05$, two-way ANOVA; Fig. 1d). b

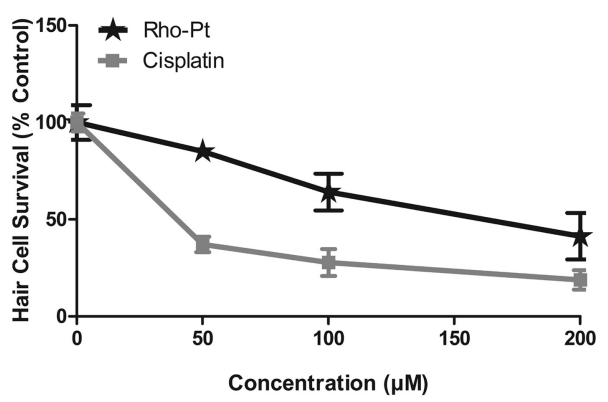

\section{$c$}

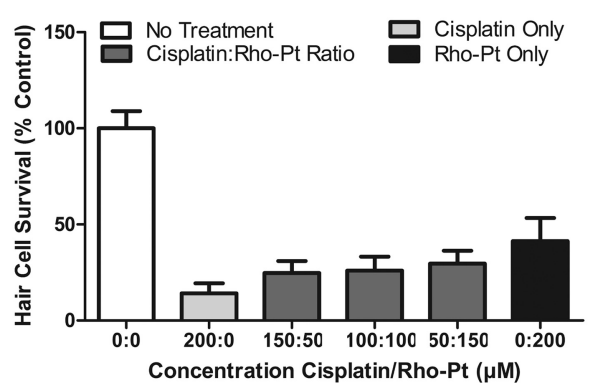

Figure 3. Rho-Pt causes dose-dependent hair cell toxicity in the lateral line. $\boldsymbol{a}$, Molecular structure of Rho-Pt (used with preatech Diagnostics, Amsterdam, The Netherlands) and cisplatin. $\boldsymbol{b}$, Dose-response functions of Rho-Pt and cis( $n=11-13$ fish; $p<0.001$, one-way ANOVA), although Rho-Pt toxicity is significantly reduced compared to cisplatin ( $<<0$. survival after treatment with variable ratios of cisplatin/Rho-Pt suggest that toxicity was additive, rather than synergistic or
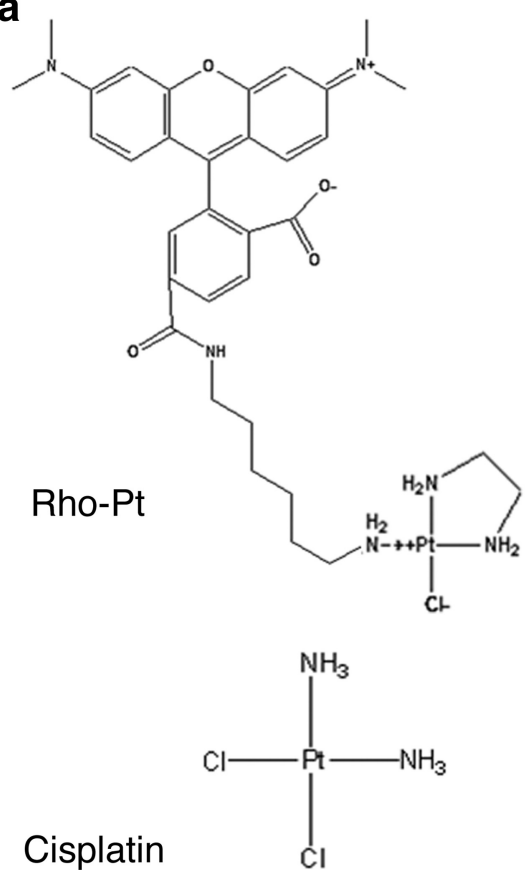

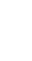



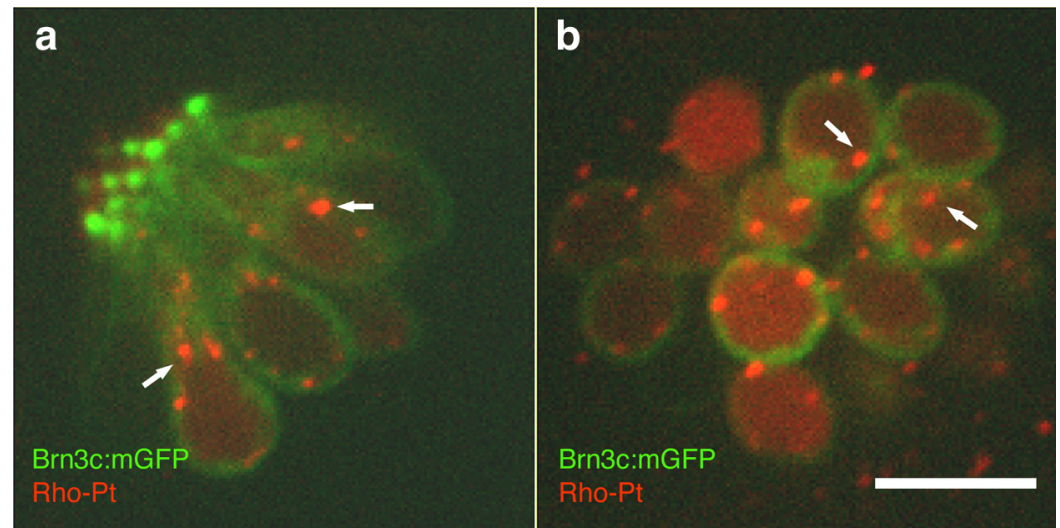

Figure 4. Rho-Pt uptake in lateral line hair cells. $\boldsymbol{a}, \boldsymbol{b}$, Single confocal longitudinal $(\boldsymbol{a})$ and axial ( $\boldsymbol{b}$ ) planes through a neuromast after Rho-Pt treatment in brn3c:mGFP fish. The hair cell membrane is outlined in green by mGFP. Diffuse Rho-Pt fluorescence is seen inside of hair cells. Arrows indicate examples of fluorescent punctae of Rho-Pt located inside of hair cells. Scale bar, $10 \mu \mathrm{m}$.

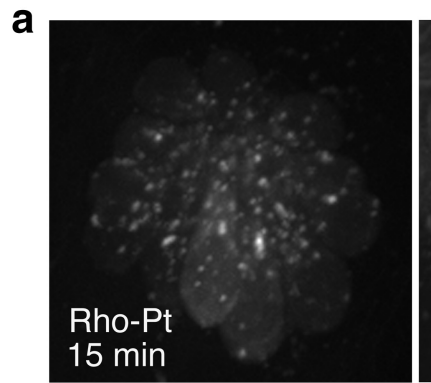

b

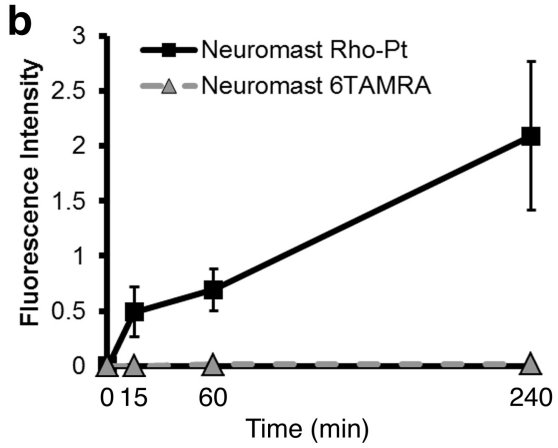

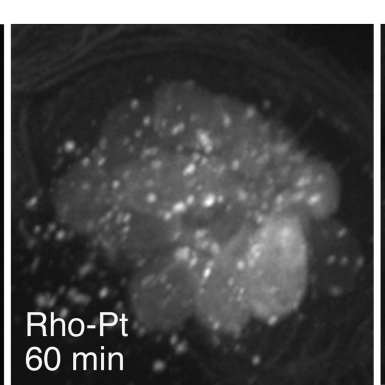

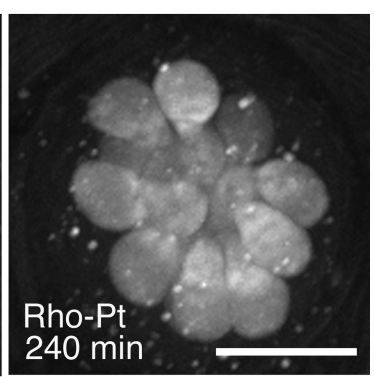

C

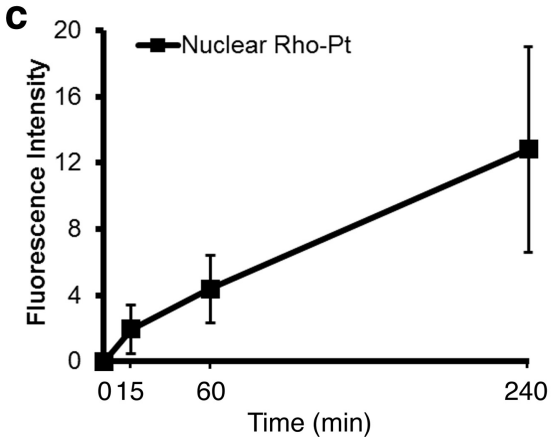

Figure 5. Time course of Rho-Pt uptake into lateral line hair cells. $\boldsymbol{a}$, Representative maximum intensity projection images of Rho-Pt uptake at 15,60, or 240 min in wild-type zebrafish. Rho-Pt is seen within cytoplasm and nuclei of lateral line hair cells within $15 \mathrm{~min}$. Scale bar, $10 \mu \mathrm{m}$. $\boldsymbol{b}$, Quantification of whole neuromast Rho-Pt and 6-TAMRA (unconjugated fluorophore) fluorescence. Fluorescence increases between $15 \mathrm{~min}$ and $4 \mathrm{~h} . n=26-29$ individual neuromasts (average, 4 per fish). There is no significant uptake of 6-TAMRA dye. c, Quantification of nuclear Rho-Pt fluorescence. The nuclear region was defined by SYTOX prelabeling. Nuclear Rho-Pt signal also increases between $15 \mathrm{~min}$ and $4 \mathrm{~h}$. For both $\boldsymbol{a}$ and $\boldsymbol{b}$, fluorescence is reported in arbitrary units of integrated fluorescence intensity. $n=26-30$ neuromasts for each data point. Error bars indicate SD.

Mutant strains of zebrafish with defective mechanotransduction were used to further test the relationship between functional mechanotransduction and cisplatin toxicity. Mutants sputnik and mariner have defective mechanotransduction due to mutations in cadherin 23 (Söllner et al., 2004) and myosin VIIAa (Ernest et al., 2000), respectively. Hair cells in both of these mutants are known to be resistant to toxicity from the aminoglycoside streptomycin (Seiler and Nicolson, 1999), but their sensitivity to cisplatin has not been reported previously. mariner and sputnik larvae ( $5 \mathrm{dpf}$ ) were treated with 25-100 $\mu \mathrm{M}$ cisplatin for $24 \mathrm{~h}$, and hair cell survival was compared to wild-type siblings receiving identical treatment. We found significant protection against cisplatin-induced hair cell death in both the mariner and sputnik mutants compared to wild-type siblings $(p<0.001$, Tukey-Kramer post-test; 50 $\mu \mathrm{M}$ data shown in Fig. $2 b$ ). For mariner, hair cell survival was maintained between $90.3 \pm 17.1 \%$ and $98.0 \pm 9.8 \%$, despite increasing concentrations of cisplatin. For sputnik, hair cell survival was maintained between $90.4 \pm 12.8 \%$ and $105.1 \pm 6.8 \%$, despite increasing concentrations of cisplatin.

We also examined the effect of tip link disruption on cisplatin-induced hair cell death. We broke hair cell tip links using 5 mM EGTA solution (Gale et al., 2001; Phillips et al., 2006) and confirmed the efficacy of the EGTA treatment on mechanotransduction by testing the effects of EGTA on neomycin toxicity and FM1-43 uptake. Similar to our findings with quinine, $5 \mathrm{~mm}$ EGTA treatment for 20 min significantly prevented neomycininduced hair cell death, with hair cell survival increasing from $27.9 \pm 5.6 \%$ in untreated controls (200 $\mu \mathrm{M}$ neomycin for $1 \mathrm{~h}$, without EGTA) to $90.0 \pm 11.0 \%$ after EGTA pretreatment $(p<0.001$, Student's $t$ test; data not shown). Evaluation of FM1-43 (3 $\mu \mathrm{M}$ for $30 \mathrm{~s}$ ) uptake into lateral line hair cells revealed that EGTA pretreatment significantly reduced FM1-43 uptake to $9.6 \pm 6.1 \%$ of control fluorescence values $(p<0.001$, one-way ANOVA), again suggesting that mechanotransduction was inhibited. We then determined whether EGTA treatment would protect against cisplatin-induced hair cell death. Indeed, 5 mm EGTA pretreatment followed by $500 \mu \mathrm{M}$ cisplatin treatment for $4 \mathrm{~h}$ significantly protected against cisplatin-induced hair cell death compared to controls ( $p<0.001$, TukeyKramer post-test; Fig. $2 c$ ), with hair cell survival increasing from $70.4 \pm 12.8 \%$ to $92.7 \pm 8.3 \%$. To prevent tip link reformation, the zebrafish were taken out of cisplatin and retreated with EGTA chelation every hour during the $4 \mathrm{~h}$ treatment (see Materials and Methods). Note, however, that the EGTA chelations interrupted the cisplatin treatment and resulted in reduced hair cell death relative to continuous cisplatin treatment. EGTA protection against longer-duration (24 h) cisplatin was not performed due to the likelihood of tip link reformation during this period (Zhao et al., 1996; Gale et al., 2001; Suli et al., 2012).

Last, we tested whether inhibition of mechanotransduction was protective against higher concentrations of cisplatin. We found that quinine-treated zebrafish as well as sputnik and mariner mutants were significantly protected against $6 \mathrm{~h}$ treatment with 250 and $500 \mu \mathrm{M}$ cisplatin $(p<0.01$, two-way ANOVA; Fig. $2 d)$. In summary, these results strongly suggest that functional mechanotransduction is required for cisplatin-induced hair cell death in the zebrafish lateral line. 
Rho-Pt is taken up by hair cells and causes hair cell death

We next examined uptake of cisplatin in hair cells, addressing whether inhibition of mechanotransduction influences uptake. We used a Rho-Pt molecule containing a cisplatin-like moiety linked to the fluorescent dye 6-TAMRA, a rhodamine derivative (Fig. $3 a$ ). Like cisplatin, this reagent is known to use its platinum moiety to bind DNA (Alers et al., 1999; van Gijlswijk et al., 2001).

To validate the use of this compound, we confirmed that it caused dosedependent toxicity to lateral line hair cells as we would expect from a cisplatin-like compound. Treatment with 50-200 $\mu \mathrm{M}$ Rho-Pt for $24 \mathrm{~h}$ resulted in significant dose-dependent toxicity ( $p<0.001$, oneway ANOVA), but of significantly less potency than unconjugated cisplatin $(p<$ 0.001, two-way ANOVA; Fig. 3b).

We then examined whether cisplatin and Rho-Pt had additive or synergistic effects. If Rho-Pt and cisplatin caused hair cell death through the same mechanism, we would expect additive or slightly antagonistic, rather than synergistic effects. We measured hair cell survival after exposure to cisplatin or Rho-Pt alone at 50, 100,150 , and $200 \mu \mathrm{M}$ concentrations, and cisplatin/Rho-Pt combination ratios of 50 $\mu \mathrm{M} / 150 \mu \mathrm{M}, 100 \mu \mathrm{M} / 100 \mu \mathrm{M}$, and 150 $\mu \mathrm{M} / 50 \mu \mathrm{M}$ (Fig. 3c). We then calculated the Chou-Talalay combination index for the two drugs (CompuSyn). This index is accepted as an effective method of quantifying synergism in drug combinations (Chou, 2006). The calculated combination index for hair cell toxicity from cisplatin and Rho-Pt was $1.09 \pm 0.15$, consistent with an additive rather than synergistic interaction between cisplatin and Rho-Pt, suggesting that the two drugs are acting through similar mechanisms.

We examined whether Rho-Pt was taken up by hair cells by exposing $5 \mathrm{dpf} A B$ wild-type zebrafish to $50 \mu \mathrm{M}$ Rho-Pt and performing in vivo imaging over $4 \mathrm{~h}$. Localization of fluorescent signal relative to the hair cell membrane was determined in single confocal image planes of $b r n 3 c$ : $m$ GFP fish, which express mGFP outlining the hair cell membrane in green. Within $15 \mathrm{~min}$, both diffuse and punctate fluorescent labeling was visualized within lateral line hair cells (Fig. 4). While most of the punctate labeling was identified within hair cells, some was also seen external to the hair cells. Since cisplatin is thought to enter the nucleus and bind DNA, we differentially quantified the level of fluorescence within the whole neuromast versus only the nuclear compartments and found an increase in fluorescence in both regions between 1 and $4 \mathrm{~h}$ (Fig. $5 a-c$ ). We also quantified the uptake of

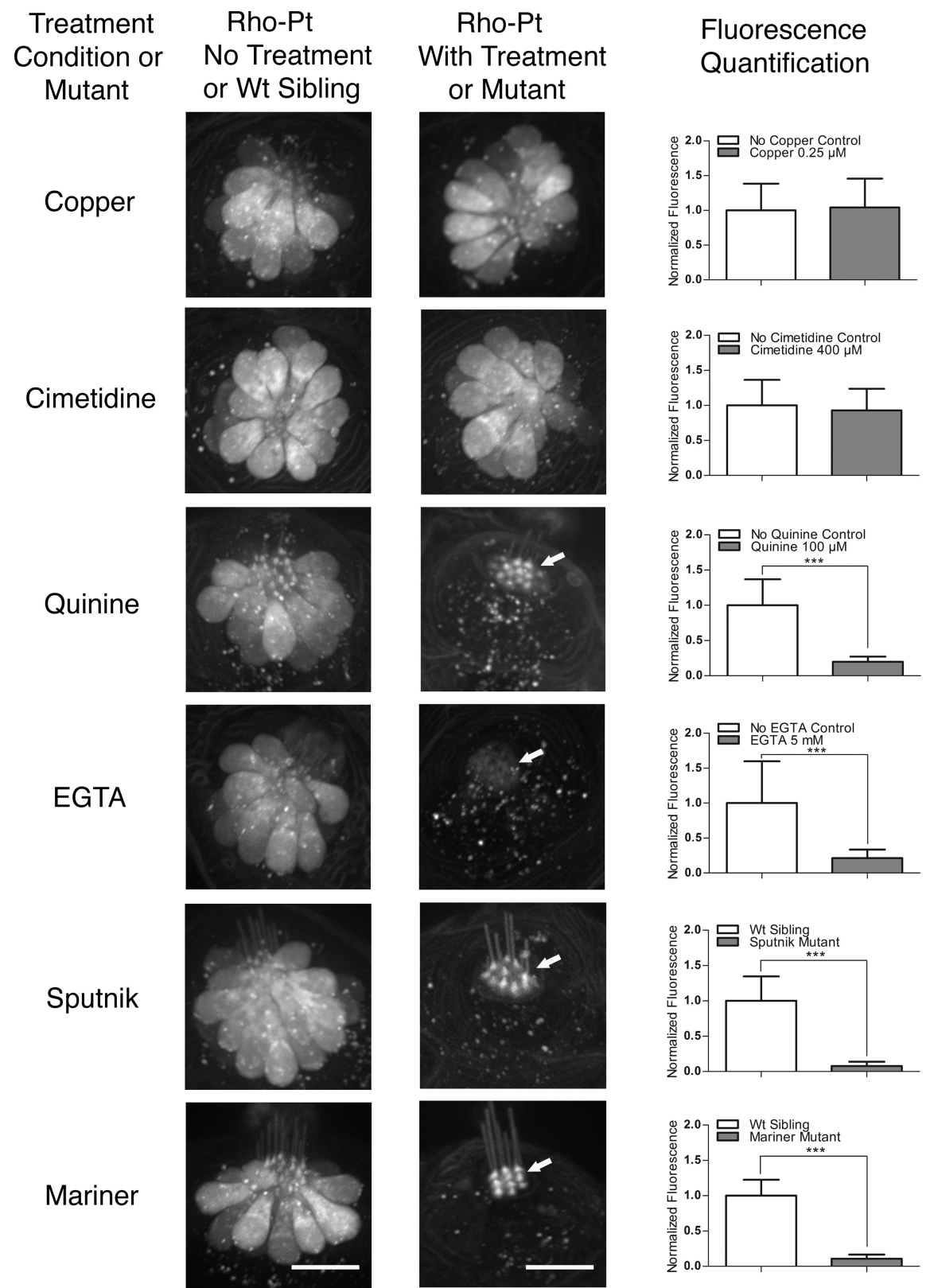

Figure 6. Functional mechanotransduction is required for uptake of Rho-Pt. Chemical or genetic inhibition of mechanotransduction leads to reduction in Rho-Pt uptake. Left panels are representative control neuromasts for each treatment group [untreated controls for copper, cimetidine, quinine, and EGTA; wild-type (Wt) siblings for sputnik and mariner]. Middle panels are representative treated or mutant neuromasts. Right panels are quantified neuromast fluorescence after $1 \mathrm{~h}$ of Rho-Pt treatment compared to controls. Inhibition of Ctr1 (by $0.25 \mu \mathrm{m}$ copper) and 0ct2 (by $400 \mu \mathrm{m}$ cimetidine) have no significant effect on Rho-Pt uptake. In contrast, inhibition of mechanotransduction by quinine $(100 \mu \mathrm{m})$ significantly reduced Rho-Pt uptake. Similarly, tip link breakage by EGTA ( $5 \mathrm{~mm}$ ) also significantly reduced Rho-Pt uptake. The sputnik and mariner mutants without functional mechanotransduction both demonstrate significant reduction in Rho-Pt uptake. Note that in conditions of reduced functional mechanotransduction, Rho-Pt signal appears to accumulate in the region of the cuticular plate and stereocilia (arrows), with reduced signal within the cell body. Scale bars: $10 \mu \mathrm{m}$. Error bars indicate SD. $n=20-30$ neuromasts per treatment group; $n=6-10$ neuromasts for wild-type siblings. ${ }^{* * *} p<0.001$ by Student's $t$ test.

unconjugated fluorescent dye (6-TAMRA) and found no significant uptake (Fig. 5b).

\section{Rho-Pt uptake into lateral line hair cells is dependent on} functional mechanotransduction

The data presented above suggest that Rho-Pt can be used as a fluorescent surrogate for cisplatin and therefore might be useful for assessing cisplatin uptake mechanisms in hair cells. Consistent with the findings presented above, neither low- 
concentration copper treatment nor high-concentration cimetidine treatment significantly altered Rho-Pt fluorescence after a $1 \mathrm{~h}$ incubation (Fig. 6). In contrast, Rho-Pt uptake after a $1 \mathrm{~h}$ incubation was dramatically reduced in conditions shown to block or profoundly decrease cisplatin toxicity, including treatment of larvae with $100 \mu \mathrm{M}$ quinine, EGTA chelation, or use of mariner and sputnik larvae (Fig. 6). Interestingly, in all conditions of reduced mechanotransduction activity, Rho-Pt signal was concentrated at the base of the kinocilia approximately at the level of the cuticular plate (Fig. 6) and dramatically reduced in the cell body. We then increased the duration of Rho-Pt exposure from $1 \mathrm{~h}$ to $4 \mathrm{~h}$ to evaluate whether uptake was blocked or simply delayed by inhibition of mechanotransduction. We found that Rho-Pt fluorescence remained dramatically and significantly blocked after treatment with quinine, and in sputnik and mariner mutants ( $p<0.001$, one-way ANOVA; Fig. 7). Together, these results suggest that reduction in mechanotransduction results in decreased cisplatin uptake and, consequently, survival of hair cells.

\section{Discussion}

Functional mechanotransduction is required for cisplatininduced hair cell death in the zebrafish lateral line

This study provides evidence for a role of functional mechanotransduction in cisplatin-induced hair cell death in the zebrafish lateral line. To date, cisplatin entry into hair cells was thought to mirror entry into cancer cells, either through the Ctr1 or Oct2 transporters (Ciarimboli et al., 2010; More et al., 2010; Ding et al., 2011). In this study, chemical inhibition of Oct 2 using cimetidine did not inhibit cisplatin-induced hair cell death. Similarly, blockade of Ctr 1 using low-concentration copper also did not protect against cisplatin-induced hair cell death. In contrast, we found that blockade of mechanotransduction using the potent mechanotransduction blocker quinine (Farris et al., 2004; Alharazneh et al., 2011) protected against cisplatin-induced hair cell death. Similarly, the myosin VIIAa mutant zebrafish mariner, with defective mechanotransduction, demonstrated complete protection against hair cell damage by cisplatin. While the finding in mariner could be related to other intracellular roles of myosin $V I I A a$, evaluation of the cadherin23 mutant zebrafish sputnik, which has a defect in mechanotransduction due to the absence of functional tip links, also demonstrated complete protection against cisplatin-induced hair cell loss. Furthermore, chemically breaking tip links using EGTA reproduced the hair cell protection seen with sputnik.

Our findings demonstrate that in the zebrafish lateral line, functional mechanotransduction plays a more significant role than either Oct 2 or Ctr 1 in cisplatin-induced hair cell death. This is contrary to findings in HEI-OC1 cells (More et al., 2010) and neonatal rat organ of Corti explants (Ding et al., 2011) where inhibition of Ctr1 with low-concentration copper was found to reduce cisplatin damage of hair cells. It is important to note that while we and others (McDermott et al., 2007) have found Ctr1 expression in zebrafish hair cells, we did not find detectable expression of Oct2 in the lateral line. This finding likely explains the lack of protection by cimetidine. It also demonstrates that the zebrafish lateral line has significant differences from the adult mammalian inner ear. Thus, findings in the zebrafish may not be applicable to mammals. However, it is critical to note that the mouse-derived HEI-OC1 cells do not have stereocilia and likely lack functional mechanotransduction (Kalinec et al., 2003), and thus also have significant differences from the adult mammalian inner ear. In addition, HEI-OC1 cells have characteristics resem-

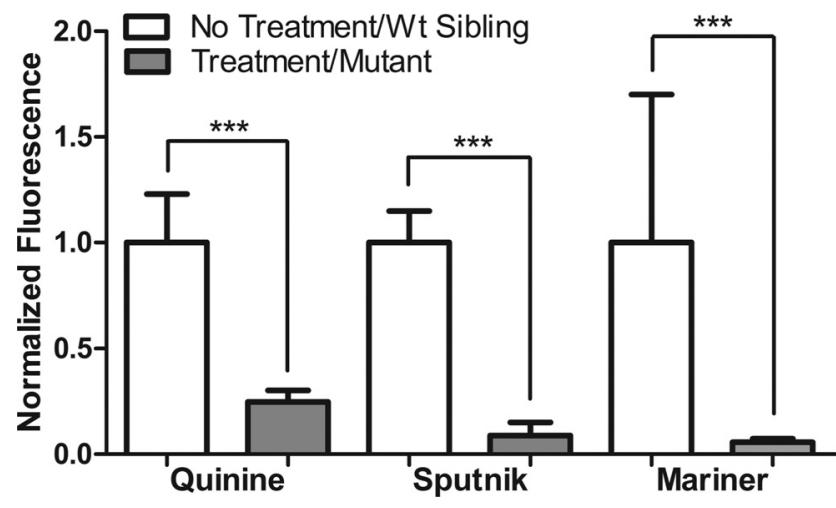

Figure 7. Rho-Pt uptake remains inhibited after $4 \mathrm{~h}$ continuous exposure. Quantification of Rho-Pt fluorescence after $4 \mathrm{~h}$ treatment (compared to $1 \mathrm{~h}$ treatment in Fig. 6). Exposure to prolonged Rho-Pt does not overcome the effect of inhibiting mechanotransduction. Rho-Pt fluorescence remains significantly decreased ( $p<0.001$ by Student's $t$ test) with quinine treatment as well as in the sputnik and mariner mutants compared to their wild-type (Wt) siblings. $n=20-24$ neuromasts per treatment group. Error bars indicate SD. ${ }^{* *} p<0.001$ by Student's $t$ test.

bling neonatal hair cells (nestin expression) and supporting cells (OCP2 expression) (Kalinec et al., 2003). Given these differences, the mechanism of cisplatin uptake in HEI-OC1 cells may not accurately represent that of an adult mammal. Similarly, it is known that the rat inner ear does not develop mature susceptibility to aminoglycosides until after postnatal day 8 (Marot et al., 1980). Thus, neonatal rat organ of Corti explants may also have large differences compared to mature mammal inner ear epithelium in the mechanism whereby hair cells are affected by cisplatin exposure.

Both Oct 2 and Ctr 1 are expressed in the stria vascularis within the mammalian cochlea. Within the stria vascularis, they might play a role in pumping cisplatin into the endolymphatic spaces of the inner ear, where cisplatin could then enter hair cells through mechanotransduction-dependent processes. Blockade of these transporters might then prevent cisplatin-induced hair cell death by preventing cisplatin from reaching the organ of Corti. Consistent with this idea, treatment of mice with cimetidine resulted in protection against cisplatin exposure (Ciarimboli et al., 2010). Additional studies in mammalian systems are certainly warranted.

\section{Rho-Pt can be used to study cisplatin uptake}

In vivo study of fluorescently conjugated drug analogs is an effective and direct method for the study of drug uptake (Steyger et al., 2003; Dai et al., 2006; Wang and Steyger, 2009). While the use of fluorescently conjugated cisplatin has been described in hair cells (Ding et al., 2011), specific use of the Rho-Pt reagent to study mechanisms of uptake has not been reported. We first examined whether Rho-Pt would have a similar damage profile to unconjugated cisplatin. Our dose-response functions demonstrated a similar but reduced damage profile for Rho-Pt when compared to cisplatin. Since cisplatin is a relatively small molecule for a drug, conjugation of any fluorophore could change the kinetics of uptake and alter the damage profile. Unfortunately, fluorophores tend to be sterically bulky. Although the rhodamine derivative 6-TAMRA compares favorably in molecular weight to many other fluorophores such as Alexa dyes and Texas Red, its conjugation to cisplatin may result in the observed decrease in toxicity.

Additional support for the use of Rho-Pt as a fluorescent proxy for cisplatin comes from experiments that block cisplatin- 

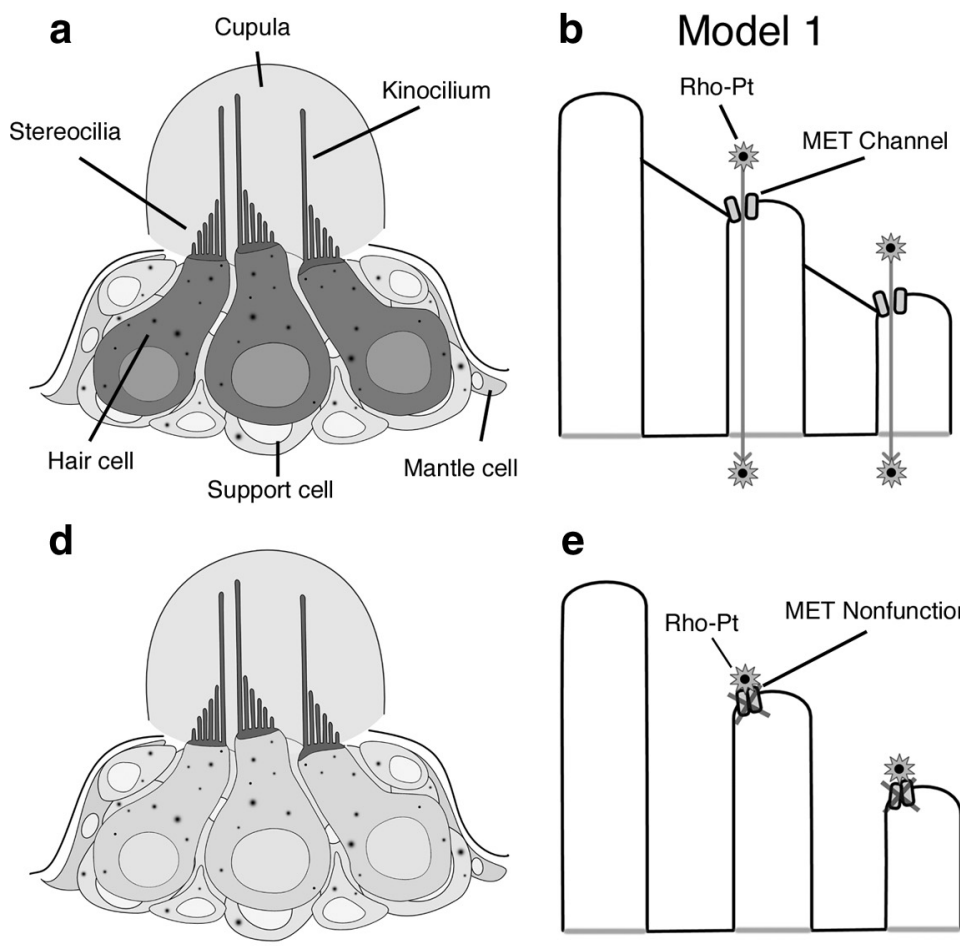

e

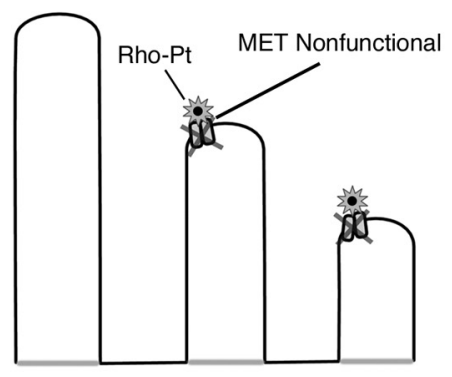

c Model 2

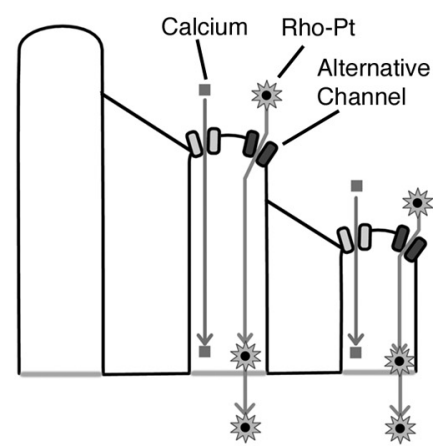

f

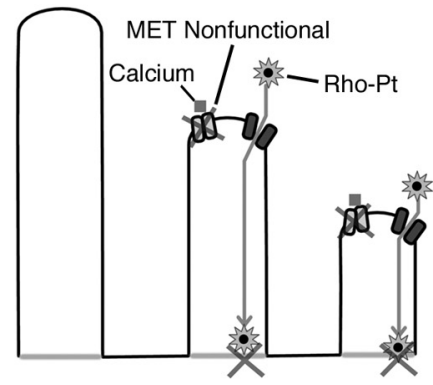

Figure 8. Two models of cisplatin entry into hair cells. $\boldsymbol{a}$, Illustration of a neuromast with functional mechanotransduction. Rho-Pt is observed inside of hair cells and at the kinocilia and the stereocilia. $\boldsymbol{b}$, Model 1:a schematic of stereocilia with active mechanotransduction illustrating a possible mode of Rho-Pt entry directly through the MET channel. $\boldsymbol{c}$, Model 2: a schematic of stereocilia representing an alternative mode of entry where Rho-Pt enters the stereocilia through a separate channel, and calcium entry through the MET channel stimulates transport of Rho-Pt from the stereocilia into the body of the hair cell. $\boldsymbol{d}$, Illustration of neuromast with impaired mechanotransduction. Rho-Pt staining is present at the kinocilia, stereocilia, and cuticular plate, but not within the hair cell body.e, Model 1 with blocked MET channel. A schematic of stereocilia with no entry of Rho-Pt through blocked MET channels is shown. Retained fluorescence of the stereocilia and kinocilia in this condition could result from binding of Rho-Pt to proteins on the outside of these structures. $f$, Model 2 with blocked MET channel. Entry of Rho-Pt through an alternative channel and blocked entry of calcium through the MET channel are shown. In this scenario, Rho-Pt enters the stereocilia, but is not transported into the hair cell body due to the absence of calcium influx through the blocked MET channel.

induced hair cell death. We found that all manipulations that reduced cisplatin-induced hair cell death (quinine, EGTA, mariner, sputnik) also significantly reduced Rho-Pt entry into hair cells. Similarly, manipulations that failed to prevent cisplatininduced hair cell death (cimetidine, copper) also failed to reduce Rho-Pt uptake. The correlation between our findings with cisplatin and Rho-Pt strongly suggest that Rho-Pt can be used as a proxy for studying cisplatin uptake.

Cisplatin is known to damage cancer cells by entering the nucleus and forming DNA adducts (Munchausen, 1974; Cohen et al., 1979). It has been assumed that similar processes occur in hair cells. Our in vivo imaging revealed that Rho-Pt was taken up rapidly into hair cells, appearing in both nuclear and extranuclear compartments. It is not known whether entry into the nucleus is critical to cisplatin-induced hair cell death since protection against cell death by inhibition of mechanotransduction reduced both the nuclear and extranuclear fluorescent signal.

\section{Proposed model for platinum uptake}

Drug uptake into hair cells has been studied extensively with aminoglycosides (Steyger et al., 2003; Dai et al., 2006; Wang and Steyger, 2009). For these drugs, both direct entry through MET channels (Marcotti et al., 2005) and apical endocytosis (Hashino and Shero, 1995) have been suggested as routes of entry into hair cells. Additionally, the process of apical endocytosis has been shown to depend on calcium and calmodulin and is inhibited when mechanotransduction is disrupted (Seiler and Nicolson, 1999). It is worth noting that inhibition of endocytosis with con- canavalin A has not been found to alter uptake of Texas Redconjugated gentamicin (Alharazneh et al., 2011). However, it is not known whether aminoglycosides and cisplatin share similar uptake mechanisms. We hypothesize that disrupting mechanotransduction could inhibit cisplatin uptake by preventing entry through the MET channel or by inhibiting apical endocytosis. Based on our findings, we propose two possible models for cisplatin entry into hair cells (Fig. 8) as follows.

In the first model, cisplatin is transported into hair cell stereocilia directly via the MET channel. Consistent with this model, cisplatin has been shown to block the MET channel in a dose- and voltage-dependent manner (Kimitsuki et al., 1993). Entry into the hair cell body from the stereocilia could occur by many different mechanisms, including diffusion or other processes dependent on calcium influx through the MET channel (Seiler and Nicolson, 1999).

In the second model, cisplatin enters stereocilia through a mechanism other than the MET channel, but relies on activity of the MET channel for transport into the hair cell body. In this model, calcium influx via the MET channel could activate calmodulin-dependent apical endocytosis and lead to transport of cisplatin from the stereocilia or cuticular plate into the hair cell body.

Our finding that Rho-Pt appears to accumulate in the region of the stereocilia and cuticular plate when mechanotransduction is blocked is most suggestive of Model 2, as we would expect no visible labeling of the hair cell in the blocked state for Model 1. It is possible, however, that the stereocilia labeling represents ad- 
herent Rho-Pt on the outer surface of the stereocilia but blocked from entry.

The mechanism of transport from the stereocilia into the hair cell body is unclear. The cuticular plate is composed of a dense network of actin largely devoid of vesicles (Tilney et al., 1980; Kachar et al., 1997). However, immediately below the base of the kinocilia is a gap in the actin matrix in which vesicles are present and in close proximity to microtubules (Kachar et al., 1997). These microtubule systems extend from the cuticular plate to the hair cell base and presumably mediate transcytosis within the cell (Leake and Snyder, 1987; Steyger et al., 1989; Kachar et al., 1997). While it is not known whether these structures play a role in intracellular drug trafficking, we hypothesize that in the mechanotransduction-blocked state, Rho-Pt/cisplatin remains trapped in this transition zone.

\section{Understanding mechanisms of cisplatin uptake may lead to new strategies of preventing cisplatin-induced hearing loss} Many potential pathways have been proposed as critical for cisplatin-induced hair cell death. These include activation of caspases, STAT1, and ROS pathways (Wang et al., 2004; Schmitt et al., 2009; Kim et al., 2010). It has also become apparent for cell death in general that inhibition of one cell death pathway can lead to activation of other cell death pathways, making a "silver bullet" agent that prevents cisplatin-induced hearing loss unlikely (Zhang et al., 2009; Zhivotovsky and Orrenius, 2010). Blockade of cisplatin uptake, however, would potentially prevent any death pathways from being initiated. Understanding the requirement of functional mechanotransduction for cisplatin-induced hair cell death thus may lead to novel approaches to prevent cisplatininduced hearing loss.

\section{References}

Alers JC, Rochat J, Krijtenburg PJ, van Dekken H, Raap AK, Rosenberg C (1999) Universal linkage system: an improved method for labeling archival DNA for comparative genomic hybridization. Genes Chromosomes Cancer 25:301-305. CrossRef Medline

Alharazneh A, Luk L, Huth M, Monfared A, Steyger PS, Cheng AG, Ricci AJ (2011) Functional hair cell mechanotransducer channels are required for aminoglycoside ototoxicity. PLoS One 6:e22347. CrossRef Medline

Chiu LL, Cunningham LL, Raible DW, Rubel EW, Ou HC (2008) Using the zebrafish lateral line to screen for ototoxicity. J Assoc Res Otolaryngol 9:178-190. CrossRef Medline

Chou TC (2006) Theoretical basis, experimental design, and computerized simulation of synergism and antagonism in drug combination studies. Pharmacol Rev 58:621-681. CrossRef Medline

Ciarimboli G, Deuster D, Knief A, Sperling M, Holtkamp M, Edemir B, Pavenstädt H, Lanvers-Kaminsky C, am Zehnhoff-Dinnesen A, Schinkel AH, Koepsell H, Jürgens H, Schlatter E (2010) Organic cation transporter 2 mediates cisplatin-induced oto- and nephrotoxicity and is a target for protective interventions. Am J Pathol 176:1169-1180. CrossRef Medline

Cohen GL, Bauer WR, Barton JK, Lippard SJ (1979) Binding of cis- and trans-dichlorodiammineplatinum(II) to DNA: evidence for unwinding and shortening of the double helix. Science 203:1014-1016. CrossRef Medline

Dai CF, Mangiardi D, Cotanche DA, Steyger PS (2006) Uptake of fluorescent gentamicin by vertebrate sensory cells in vivo. Hear Res 213:64-78. CrossRef Medline

Ding D, He J, Allman BL, Yu D, Jiang H, Seigel GM, Salvi RJ (2011) Cisplatin ototoxicity in rat cochlear organotypic cultures. Hear Res 282:196203. CrossRef Medline

Ernest S, Rauch GJ, Haffter P, Geisler R, Petit C, Nicolson T (2000) Mariner is defective in myosin VIIA: a zebrafish model for human hereditary deafness. Hum Mol Genet 9:2189-2196. CrossRef Medline

Farris HE, LeBlanc CL, Goswami J, Ricci AJ (2004) Probing the pore of the auditory hair cell mechanotransducer channel in turtle. J Physiol 558: 769-792. CrossRef Medline
Filipski KK, Loos WJ, Verweij J, Sparreboom A (2008) Interaction of Cisplatin with the human organic cation transporter 2. Clin Cancer Res 14:3875-3880. CrossRef Medline

Gale JE, Marcotti W, Kennedy HJ, Kros CJ, Richardson GP (2001) FM1-43 dye behaves as a permeant blocker of the hair-cell mechanotransducer channel. J Neurosci 21:7013-7025. Medline

Granato M, van Eeden FJ, Schach U, Trowe T, Brand M, Furutani-Seiki M, Haffter P, Hammerschmidt M, Heisenberg CP, Jiang YJ, Kane DA, Kelsh RN, Mullins MC, Odenthal J, Nüsslein-Volhard C (1996) Genes controlling and mediating locomotion behavior of the zebrafish embryo and larva. Development 123:399-413. Medline

Harris JA, Cheng AG, Cunningham LL, MacDonald G, Raible DW, Rubel EW (2003) Neomycin-induced hair cell death and rapid regeneration in the lateral line of zebrafish (Danio rerio). J Assoc Res Otolaryngol 4:219-234. CrossRef Medline

Hashino E, Shero M (1995) Endocytosis of aminoglycoside antibiotics in sensory hair cells. Brain Res 704:135-140. CrossRef Medline

Hernández PP, Moreno V, Olivari FA, Allende ML (2006) Sub-lethal concentrations of waterborne copper are toxic to lateral line neuromasts in zebrafish (Danio rerio). Hear Res 213:1-10. CrossRef Medline

Ishida S, Lee J, Thiele DJ, Herskowitz I (2002) Uptake of the anticancer drug cisplatin mediated by the copper transporter Ctr1 in yeast and mammals. Proc Natl Acad Sci U S A 99:14298-14302. CrossRef Medline

Kachar B, Battaglia A, Fex J (1997) Compartmentalized vesicular traffic around the hair cell cuticular plate. Hear Res 107:102-112. CrossRef Medline

Kalinec GM, Webster P, Lim DJ, Kalinec F (2003) A cochlear cell line as an in vitro system for drug ototoxicity screening. Audiol Neurootol 8:177189. CrossRef Medline

Kim HJ, Lee JH, Kim SJ, Oh GS, Moon HD, Kwon KB, Park C, Park BH, Lee HK, Chung SY, Park R, So HS (2010) Roles of NADPH oxidases in cisplatin-induced reactive oxygen species generation and ototoxicity. J Neurosci 30(11):3933-3946. CrossRef

Kimitsuki T, Nakagawa T, Hisashi K, Komune S, Komiyama S (1993) Cisplatin blocks mechano-electric transducer current in chick cochlear hair cells. Hear Res 71:64-68. CrossRef Medline

Knight KR, Kraemer DF, Neuwelt EA (2005) Ototoxicity in children receiving platinum chemotherapy: underestimating a commonly occurring toxicity that may influence academic and social development. J Clin Oncol 23:8588-8596. CrossRef Medline

Knight KR, Kraemer DF, Winter C, Neuwelt EA (2007) Early changes in auditory function as a result of platinum chemotherapy: use of extended high-frequency audiometry and evoked distortion product otoacoustic emissions. J Clin Oncol 25:1190-1195. CrossRef Medline

Leake PA, Snyder RL (1987) Uptake of horseradish peroxidase from perilymph by cochlear hair cells. Hear Res 25:153-171. CrossRef Medline

Mackenzie SM, Raible DW (2012) Proliferative regeneration of zebrafish lateral line hair cells after different ototoxic insults. PLoS One 7:e47257. CrossRef Medline

Marcotti W, van Netten SM, Kros CJ (2005) The aminoglycoside antibiotic dihydrostreptomycin rapidly enters mouse outer hair cells through the mechano-electrical transducer channels. J Physiol 567:505-521. CrossRef Medline

Marot M, Uziel A, Romand R (1980) Ototoxicity of kanamycin in developing rats: relationship with the onset of the auditory function. Hear Res 2:111-113. CrossRef Medline

McDermott BM Jr, Baucom JM, Hudspeth AJ (2007) Analysis and functional evaluation of the hair-cell transcriptome. Proc Natl Acad Sci U S A 104:11820-11825. CrossRef Medline

Minematsu T, Iwai M, Umehara K, Usui T, Kamimura H (2010) Characterization of human organic cation transporter 1 (OCT1/SLC22A1)- and OCT2 (SLC22A2)-mediated transport of 1-(2-methoxyethyl)-2-methyl-4,9-dioxo3-(pyrazin-2-ylmethyl)-4,9-dihydro-1H-naphtho[2,3-d]imidazolium bromide (YM155 monobromide), a novel small molecule survivin suppressant. Drug Metab Dispos 38:1-4. Medline

More SS, Akil O, Ianculescu AG, Geier EG, Lustig LR, Giacomini KM (2010) Role of the copper transporter, CTR1, in platinum-induced ototoxicity. J Neurosci 30(28):9500-9509.

Munchausen LL (1974) The chemical and biological effects of cisdichlorodiammineplatinum (II), an antitumor agent, on DNA. Proc Natl Acad Sci U S A 71:4519-4522. CrossRef Medline

Okuda M, Urakami Y, Saito H, Inui K (1999) Molecular mechanisms of 
organic cation transport in OCT2-expressing Xenopus oocytes. Biochim Biophys Acta 1417:224-231. CrossRef Medline

Ou HC, Raible DW, Rubel EW (2007) Cisplatin-induced hair cell loss in zebrafish (Danio rerio) lateral line. Hear Res 233:46-53. CrossRef Medline

Owens KN, Coffin AB, Hong LS, Bennett KO, Rubel EW, Raible DW (2009) Response of mechanosensory hair cells of the zebrafish lateral line to aminoglycosides reveals distinct cell death pathways. Hear Res 253: 32-41. CrossRef Medline

Pabla N, Murphy RF, Liu K, Dong Z (2009) The copper transporter Ctr1 contributes to cisplatin uptake by renal tubular cells during cisplatin nephrotoxicity. Am J Physiol Renal Physiol 296:F505-F511. Medline

Phillips KR, Tong S, Goodyear R, Richardson GP, Cyr JL (2006) Stereociliary myosin- $1 \mathrm{c}$ receptors are sensitive to calcium chelation and absent from cadherin 23 mutant mice. J Neurosci 26:10777-10788. CrossRef Medline

Raible DW, Kruse GJ (2000) Organization of the lateral line system in embryonic zebrafish. J Comp Neurol 421:189-198. CrossRef Medline

Rybak LP (1981) Cis-platinum associated hearing loss. J Laryngol Otol 95: 745-747. CrossRef Medline

Schindelin J, Arganda-Carreras I, Frise E, Kaynig V, Longair M, Pietzsch T, Preibisch S, Rueden C, Saalfeld S, Schmid B, Tinevez JY, White DJ, Hartenstein V, Eliceiri K, Tomancak P, Cardona A (2012) Fiji: an opensource platform for biological-image analysis. Nat Methods 9:676-682. CrossRef Medline

Schmitt NC, Rubel EW, Nathanson NM (2009) Cisplatin-induced hair cell death requires STAT1 and is attenuated by epigallocatechin gallate. J Neurosci 29:3943-3951. CrossRef Medline

Seiler C, Nicolson T (1999) Defective calmodulin-dependent rapid apical endocytosis in zebrafish sensory hair cell mutants. J Neurobiol 41:424-434. CrossRef Medline

Skinner R, Pearson AD, Amineddine HA, Mathias DB, Craft AW (1990) Ototoxicity of cisplatinum in children and adolescents. Br J Cancer 61: 927-931. CrossRef Medline

Söllner C, Rauch GJ, Siemens J, Geisler R, Schuster SC, Müller U, Nicolson T (2004) Mutations in cadherin 23 affect tip links in zebrafish sensory hair cells. Nature 428:955-959. CrossRef Medline

Stewart DJ (2007) Mechanisms of resistance to cisplatin and carboplatin. Crit Rev Oncol Hematol 63:12-31. CrossRef Medline

Steyger PS, Furness DN, Hackney CM, Richardson GP (1989) Tubulin and microtubules in cochlear hair cells: comparative immunocytochemistry and ultrastructure. Hear Res 42:1-16. CrossRef Medline

Steyger PS, Peters SL, Rehling J, Hordichok A, Dai CF (2003) Uptake of gentamicin by bullfrog saccular hair cells in vitro. J Assoc Res Otolaryngol 4:565-578. CrossRef Medline

Suli A, Watson GM, Rubel EW, Raible DW (2012) Rheotaxis in larval zebrafish is mediated by lateral line mechanosensory hair cells. PLoS One 7:e29727. CrossRef Medline

Thisse B, Heyer V, Lux A, Alunni V, Degrave A, Seiliez I, Kirchner J, Parkhil JP, Thisse C (2004) Spatial and temporal expression of the zebrafish genome by large-scale in situ hybridization screening. Methods Cell Biol 77:505-519. CrossRef Medline

Thisse C, Thisse B (2008) High-resolution in situ hybridization to wholemount zebrafish embryos. Nat Protoc 3:59-69. CrossRef Medline

Tilney LG, Derosier DJ, Mulroy MJ (1980) The organization of actin filaments in the stereocilia of cochlear hair cells. J Cell Biol 86:244-259. CrossRef Medline

Ton C, Parng C (2005) The use of zebrafish for assessing ototoxic and otoprotective agents. Hear Res 208:79-88. CrossRef Medline

van Gijlswijk RP, Talman EG, Janssen PJ, Snoeijers SS, Killian J, Tanke HJ, Heetebrij RJ (2001) Universal Linkage System: versatile nucleic acid labeling technique. Expert Rev Mol Diagn 1:81-91. CrossRef Medline

Vlasits AL, Simon JA, Raible DW, Rubel EW, Owens KN (2012) Screen of FDA-approved drug library reveals compounds that protect hair cells from aminoglycosides and cisplatin. Hear Res 294:153-165.

Wang J, Ladrech S, Pujol R, Brabet P, Van De Water TR, Puel JL (2004) Caspase inhibitors, but not c-Jun NH2-terminal kinase inhibitor treatment, prevent cisplatin-induced hearing loss. Cancer Res 64:9217-9224. CrossRef Medline

Wang Q, Steyger PS (2009) Trafficking of systemic fluorescent gentamicin into the cochlea and hair cells. J Assoc Res Otolaryngol 10:205-219. CrossRef Medline

Westerfield M (2000) The zebrafish book: a guide for the laboratory use of zebrafish (Danio rerio). Eugene, OR: University of Oregon.

Williams JA, Holder N (2000) Cell turnover in neuromasts of zebrafish larvae. Hear Res 143:171-181. CrossRef Medline

Xiao T, Roeser T, Staub W, Baier H (2005) A GFP-based genetic screen reveals mutations that disrupt the architecture of the zebrafish retinotectal projection. Development 132:2955-2967. CrossRef Medline

Zhang DW, Shao J, Lin J, Zhang N, Lu BJ, Lin SC, Dong MQ, Han J (2009) RIP3, an energy metabolism regulator that switches TNF-induced cell death from apoptosis to necrosis. Science 325:332-336. CrossRef Medline

Zhao Y, Yamoah EN, Gillespie PG (1996) Regeneration of broken tip links and restoration of mechanical transduction in hair cells. Proc Natl Acad Sci U S A 93:15469-15474. CrossRef Medline

Zhivotovsky B, Orrenius S (2010) Cell cycle and cell death in disease: past, present and future. J Intern Med 268:395-409. CrossRef Medline 